\title{
Monomorphic Epitheliotropic Intestinal T Cell Lymphoma With Lower Gastrointestinal Hemorrhage: A Case Report and Literature Review
}

\section{Cheng Zhou}

Henan University of Chinese Medicine https://orcid.org/0000-0002-0592-3504

Lin Yang ( $\nabla$ doctor0523@163.com )

Xianyang Central Hosptial

\section{Hai-Juan Xiao}

Shaanxi University of Chinese Medicine

\section{Xiao-Yan Ma}

Xianyang Central Hosptial

\section{Rui-Ni Li}

Xianyang Central Hosptial

\section{Yu Fang}

Shaanxi University of Chinese Medicine

\section{Case Report}

Keywords: Case report, Lymphoma, Non-Hodgkin lymphoma, Enteropathy-associated T cell lymphoma, Monomorphic epitheliotropic intestinal T cell lymphoma, Gastrointestinal hemorrhage, Pathology

Posted Date: October 29th, 2021

DOl: https://doi.org/10.21203/rs.3.rs-970715/v1

License: (9) This work is licensed under a Creative Commons Attribution 4.0 International License. Read Full License 


\section{Abstract}

Enteropathy-associated T cell lymphoma(EATL) is a kind of malignant lymphoma with strong invasiveness. Due to poor effect of conventional symptomatic treatment, the prognosis is not as good as other T-cell lymphomas. A 63-year-old man was admitted to our hospital due to hematochezia. No definite cause was found by electronic gastroscopy and electronic colonoscopy. After symptomatic treatment, the patient's condition did not show significant remission. However, he refused further examination and was discharged. Two months later, the man was admitted to our hospital again due to hematochezia. The site of the lesion was found by capsule endoscopy and small intestinal endoscopy, and the nature of the lesion was confirmed by immunohistochemistry. The patient received chemotherapy and autologous stem cell transplantation after a definite diagnosis. No recurrence or metastasis has been found in an 18months follow-up after treatment.

\section{Background}

Lymphoma is a class of hematological malignancies that arise from lymphoid tissue, including Hodgkin lymphoma and non-Hodgkin lymphoma. The digestive tract is the most common site for extranodal nonHodgkin lymphoma. Diffuse large B-cell type, mantle cell type and follicular type were the main histological classification, while T cell lymphoma is rare. Enteropathy-associated T cell lymphoma(EATL) is a type of non-Hodgkin lymphoma, which accounts for only $5.4 \%$ of all lymphomas, compared with $9.1 \%$ in Europe and $1.9 \%$ in Asia, median morbidity age is about 60 years old, it's more common in men than women $(1,2)$. It is often misdiagnosed due to non-specific with minor endoscopic abnormalities. The diagnosis is mainly based on histological observation, immunohistochemical staining, EBER detection and gene rearrangement detection. Currently, there is a lack of standard and consensus for the treatment of EATL, most of which are based on expert opinion and exploratory therapy. In this paper, a case of enteropathy-associated T cell lymphoma type II (monomorphic epitheliotropic intestinal T-cell lymphoma) with recurrent lower gastrointestinal hemorrhage as the main symptom was reported. The diagnosis methods, treatment regimens and clinical effects of enteropathy-associated T cell lymphoma reported in recent years were also summarized and analyzed.

\section{Case Presentation}

On July 21, 2019, a 63-year-old man was admitted to our hospital with recurrent black stool for 2 days. Two days ago, the patient had no obvious inducement to defecate melena, accompanied by dizziness and fatigue, and immediately went to the local hospital to see a doctor. The symptoms were not relieved after taking hemostatic drugs in the local hospital and transferred to the emergency department of Xianyang Central Hospital for further diagnosis and treatment afterward. Electronic gastroscopy showed scattered flaky erosion of the gastric fundus, punctate erythema of the gastric body, and the diagnosis was chronic non-atrophic gastritis with erosion. Electronic colonoscopy showed scattered punctate erosion of the ileocecal mucosa, and the diagnosis was ileocecal valvular inflammation. No obvious abnormality was found in enhanced CT of the chest and abdomen. The patient refused further 
examination and was discharged from the hospital. On September 4, 2019, the patient was admitted to our hospital again with recurrent black stool for 2 months. Capsule endoscopy (Fig. 1A) showed that the capsule entered the duodenum through the pylorus in 37 minutes and 26 seconds, the bulbar mucosa was congested and edematous, then the capsule quickly entered the jejunum, although the intestinal preparation was poor, multiple deep basement depressions could be seen in the local jejunal mucosa. Accordingly, diagnosis of ulceration and tumor may be considered. Single balloon enteroscopy (Fig. 1B) was performed and 6 biopsies were taken. Under enteroscopy, large patches of ulcerative lesions about $50 \mathrm{~cm}$ from the great nipple of the duodenum were seen, covered with gray-and-white moss, with active blood oozing, and the biopsy was tough. Considering the possibility of Crohn's disease and lymphoma, the biopsy is recommended to determine the nature. Morphological observation of biopsy tissue (Fig. 1C,1D): there was mainly lymphocyte infiltration in jejunal mucosa, most of them were single round lymphocytes, a few of them were nuclear-twisted cells, the cells were equal, heteromorphic, lightly stained cytoplasm, obvious nucleolus and mitosis. Immunohistochemical staining (Fig. 2A-2D): lymphocyte CD3 (Fig. 2A), CD8 (Fig. 2B), CD56 (Fig. 2C) were positive, CD20 (B cell expression marker) and in situ hybridizations EBER were negative, the proliferation index of Ki-67(Fig. 2D) was $80 \%$. The pathological results were consistent with T-cell lymphoma, monomorphic epitheliotropic T-cell lymphoma (type II of enteropathy-associated T cell lymphoma) was considered in the classification. After a clear diagnosis, he was transferred to Xijing Hospital of Air Force military Medical University for chemotherapy and autologous stem cell transplantation. No recurrence or metastasis has been found in an 18-months follow-up after treatment.

\section{Discussion And Conclusion}

In 2001, the World Health Organization (WHO) divided EATL into two types: intestinal T-cell lymphoma and enteropathy-associated T-cell lymphoma. Owing to many subtypes of T-cell lymphoma show the symptoms of intestinal diseases, the differential diagnosis between EATL and other T-cell lymphomas

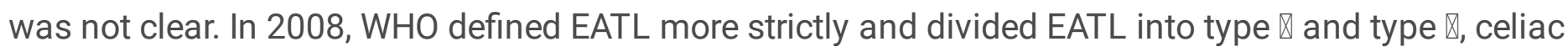
disease and the positive expression of HLA-DQA $1 * 0501$, HLA-DQB $1 * 0201$ gene were associated with type I. As a monomorphic variant of type I, type II had unique cell morphology and immunophenotype(3). The

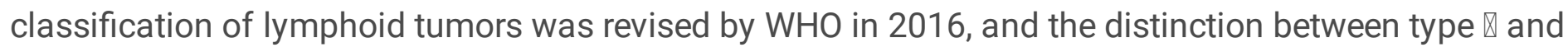
type $\otimes$ of EATL is clearer, type II of EATL is officially named monomorphic epitheliotropic intestinal T-cell lymphoma (MEITL)(4).

EATL originates from intraepithelial lymphocytes (IELs), which is different from the origin cells of peripheral T-cell lymphoma, the T-cell subsets of EATL are mainly composed of $\gamma \delta$ - T cell, which has more complex phenotypes, Overexpression of NK like cytotoxicity and interferon- $\gamma$ signaling pathway is an important manifestation(5). Moffitt(6) found that the overexpression of interferon- $\gamma$ signaling pathway is more obvious in type I EATL, which is consistent with the increase of interferon-y secretion in patients with chylorrhea. Most genes in MEITL are involved in the natural killer-like cytotoxicity pathway. In terms of chromosome changes, a series of genomic hybridization analyses in Asia and Western countries 
showed some similarities, EATL often shows amplification of chromosome 1q, 5q, 7q, 8q and 9q, and deletion of $8 p, 9 p$ and $13 q(6,7)$.

The differentiation of EATL types is mainly based on the cell morphology and immunophenotype, the tumor cells of type I EATL are medium or large-sized and diversified in morphology, immunophenotypes expressions are usually $\mathrm{CD} 3^{+}, \mathrm{CD}_{4} 3^{+}, \mathrm{CD} 5^{-}, \mathrm{CD}^{+}, \mathrm{CD} 8^{ \pm}, \mathrm{CD} 4^{-}, \mathrm{CD} 103^{+}, \mathrm{TCR}^{ \pm}$with chromosome $1 \mathrm{q}$ and $5 q$ amplification, the gene expression of STAT3, STAT5A, IRF1 and IRF4 is higher in type I than in type II (4). The high expression of transglutaminase 2 (TGM 2) is closely related to chylorrhea in type I, insisting on a gluten-free diet is an important method to improve prognosis (8). MEITL is not closely related to celiac disease, the immunophenotype expressions of MEITL are often CD $8{ }^{+}, \mathrm{CD} 56^{+}, \mathrm{TIA}-1^{+}$ with chromosome $8 \mathrm{q}$ amplification. The tumor cells are small and medium-sized, the nucleolus is darkly stained with round mononuclear cells and accompanied by nuclear division or necrosis, MAPK signaling is up-regulated, FASLG, SYK and TGBR1 genes are highly expressed $(7,9)$.

The onset of EATL is relatively occult. Half of the patients only have symptoms such as abdominal pain and diarrhea in the early stage, and most of them are hospitalized with acute intestinal obstruction or intestinal perforation in the late stage. In this case, gastrointestinal bleeding was the main clinical manifestation in both admissions, accounting for about $10 \%$ of the clinical features. During the first hospitalization, the patient's condition did not appear obvious remission after symptomatic treatment such as acid suppression and gastric protection, anti-inflammatory hemostasis, anti-infection, maintenance of water and electrolyte balance. However, the patient refused further treatment, resulting in delayed diagnosis and missed the best period of treatment. Most EATL lesions occur in the jejunum or ileum, and it is difficult to accurately detect the lesion site by electronic gastroscope and colonoscopy. Although some studies have shown that small intestinal CT enterography ( CTE ) can clearly show the abnormal changes of intestinal wall and extra-intestinal cavity, it is not as good as small intestinal endoscopy and capsule endoscopy to directly observe tissue lesions, and obtain more disease information and diagnostic ideas(10). Local erosion, ulcer and mass are the common manifestations of EATL under endoscopy. It can present segmental multiple lesions, often involving mesenteric lymph nodes, liver, spleen, lung and other parts, resulting in corresponding systemic changes. The histological observation of EATL is greatly affected by the location of biopsy. If the location of biopsy tissue is shallower than that of the lamina propria and mucosal muscular layer, it may only show crypt hyperplasia or gland atrophy, and tumor cells are often mixed with tissue cells, plasma cells and eosinophils. This mixed infiltration of cancer and inflammation will cover up tumor cells and greatly increase the probability of misdiagnosis. The preliminary diagnosis is mostly misdiagnosed as peptic ulcer, digestive tract adenocarcinoma, inflammatory bowel disease, Behcet syndrome, intestinal tuberculosis and other abdominal diseases. Multiple endoscopic and biopsy examinations were performed to determine the nature of the disease, and multidisciplinary discussions were actively carried out with the pathology and imaging departments. The improvement of immunohistochemistry and gene rearrangement tests is the key means to avoid a missed diagnosis of lymphoma. 
In addition to the identification with abdominal diseases, MEITL also needs to be distinguished from type I EATL, peripheral T-cell lymphoma not otherwise specified ( PTCL-NOS ), B-cell lymphoma, extranodal nasal NK / T-cell lymphoma ( ENKTL ) and other lymphological diseases.

Among them, the more important is the differential diagnosis with indolent T-cell lymphoproliferative disorder of the gastrointestinal tract. Since the incidence of indolent T-cell lymphoproliferative disorder of the gastrointestinal tract is relatively low, the studies are mostly concentrated in a small number of case reports. In 2017, WHO classified it as a new temporary entity into the classification of lymphatic tumors(11). The incidence sites are mainly concentrated in the small intestine and colon, and the incidence rates of esophagus and stomach are low, which overlaps with the common incidence sites of EATL(12). Superficial erosion and polypoid degeneration are common manifestations of indolent T-cell lymphoproliferative disorder of the gastrointestinal tract under endoscopy. Compared with EATL, EATL is less invasive and has few tumors infiltrating the whole intestinal wall(8).

Most of the immunophenotypes are $\mathrm{CD} 3^{+}, \mathrm{CD} 4^{+}, \mathrm{CD} 8^{+}, \mathrm{TIA}^{-1}{ }^{+}, \mathrm{CD} 56^{-}, \mathrm{CD} 30^{-}, \mathrm{Ki}-67$ cell proliferation index is less than $10 \%$, which are often accompanied by TCR $\beta$ or $y$ rearrangement, but there is no mutation of STAT3, STAT5B, SETD2 and other genes in EATL(13). Indolent T-cell lymphoproliferative disorder of the gastrointestinal tract has poor response to conventional chemotherapy, but steroids can improve symptoms. Due to the slow progression of the disease and the low probability of transforming into invasive lymphoma, the survival time of patients is often more than ten years.

EATL is a complex disease affected by multiple genes which have strong invasiveness, poor effect of conventional symptomatic treatment and poor prognosis than other T cell lymphomas. Mutations in DNA damage response and repair genes ( TP53, BCL11B, BRIP1), apoptosis-related genes DAPK3 and cell cycle transcription factor $B B X$ frequently occur in $\operatorname{EATL}(1,6)$. In the past, most patients were treated with surgery combined with systemic chemotherapy drugs. However, due to the frequent spread of tumor cells and more tumor-infiltrating tissue, complete resection is almost impossible, and the incidence of postoperative complications is high, surgical treatment often has little benefit(14). CHOP regimen based on anthracycline (cyclophosphamide, doxorubicin, vincristine, prednisolone) is the most commonly used chemotherapy regimen for EATL, but it has serious toxic and side effects, and most EATL is less sensitive to chemotherapy $(15,16)$. Although the immunophenotypes of EATL patients with type I are different from those of MEITL patients, the development of tumor cells still follows similar genetic pathways. SETD 2 gene is the most common silent gene in EATL, and JAK-STAT and GPCR signaling pathways are the most frequently mutated pathways(23). Targeted regulation of these sites may be a potential treatment for EATL in the future. In recent years, CVAD regimen (cyclophosphamide, vincristine, doxorubicin, dexamethasone), autologous stem cell transplantation(ASCT), histone deacetylase inhibitor, anti-CD 52 antibody, and other drugs have also been used in the treatment of EATL. Autologous stem cell transplantation can significantly improve the prognosis of EATL, prolong progression-free survival and overall survival(16-22). Due to the lack of relevant treatment standards and consensus on EATL, most treatments are based on expert advice and exploratory treatment. Combined treatment including surgical resection, systemic chemotherapy, and autologous stem cell transplantation is an effective way to 
improve the therapeutic effect. If EATL patients were successfully treated with autologous stem cell transplantation, the total remission rate (ORR), progression-free survival time (PFS) and total survival time (OS) were comparable to those of other types of peripheral T-cell lymphoma (Table 1). In addition, car-t is an important method for the treatment of recurrent B-cell lymphoma with high clinical response rate. In recent studies, it was found that car-t can achieve long-term remission of the disease in the treatment of recurrent EATL that cannot undergo ASCT(24). Based on the gradual exploration of prospective clinical trials, we believe that the treatment of EATL will continue to perfect, and the survival time and quality of patients will continue to be improved.

Table 1

Treatment and follow-up results of enteropathy-associated T cell lymphoma

\begin{tabular}{|c|c|c|c|c|c|}
\hline Project & Figure & Type & Treatment & PFS & os \\
\hline \multirow[t]{2}{*}{$\begin{array}{l}\text { Sieniawski } \\
\text { et al. }^{16}\end{array}$} & 26 & $\begin{array}{l}\text { EATL } \otimes \\
\text { and } \nabla\end{array}$ & IVE/MTX-ASCT & 5 years $52 \%$ & 5 years $60 \%$ \\
\hline & 31 & $\begin{array}{l}\text { EATL } \otimes \\
\text { and } \rrbracket\end{array}$ & Chop & 5 years $22 \%$ & 5 years $22 \%$ \\
\hline $\begin{array}{l}\text { Phillips et } \\
\text { al. }^{18}\end{array}$ & 11 & $\begin{array}{l}\text { EATL } \otimes \\
\text { and } \nabla\end{array}$ & IVE-MTX-ASCT & 1 year $45 \%$ & 1 year $45 \%$ \\
\hline $\begin{array}{l}\text { Gale et } \\
\text { al. }{ }^{14}\end{array}$ & 31 & $\begin{array}{l}\text { EATL } \otimes \\
\text { and } \otimes\end{array}$ & $\begin{array}{l}\text { Chemotherapy, } \\
\text { surgery }\end{array}$ & $\begin{array}{l}1 \text { year } 19.4 \% \varangle 5 \\
\text { years } 3.2 \%\end{array}$ & $\begin{array}{l}1 \text { year } 38.7 \% \otimes 5 \\
\text { years } 19.7 \%\end{array}$ \\
\hline $\begin{array}{l}\text { Mark et } \\
\text { al. }{ }^{19}\end{array}$ & 6 & $\begin{array}{l}\text { EATL } \otimes \\
\text { and } \otimes\end{array}$ & $\begin{array}{l}\text { Chemotherapy, } \\
\text { surgery and ASCT }\end{array}$ & & $\begin{array}{l}1 \text { year } 83.3 \% \bigotimes 3 \\
\text { years } 50 \%\end{array}$ \\
\hline $\begin{array}{l}\text { Jantunen } \\
\text { et al. }{ }^{20}\end{array}$ & 44 & $\begin{array}{l}\text { EATL } \otimes \\
\text { and } \otimes\end{array}$ & $\begin{array}{l}\text { Chemotherapy and } \\
\text { ASCT }\end{array}$ & 4 years $54 \%$ & 4 years $59 \%$ \\
\hline $\begin{array}{l}\text { Francesco } \\
\text { et al. }^{21}\end{array}$ & 21 & $\begin{array}{l}\text { EATL } \otimes \\
\text { and } \otimes\end{array}$ & Chop and ASCT & 5 years 38\% & 5 years $48 \%$ \\
\hline Tse et al. ${ }^{22}$ & 36 & EATL $\otimes$ & $\begin{array}{l}\text { Chemotherapy, } \\
\text { surgery and ASCT }\end{array}$ & $\begin{array}{l}1 \text { year } 21 \% \square \\
\text { median } 1 \text { month }\end{array}$ & $\begin{array}{l}1 \text { years } 36 \% \square \\
\text { median } 7 \text { months }\end{array}$ \\
\hline \multirow[t]{4}{*}{$\begin{array}{l}\text { Petula et } \\
\text { al. }^{15}\end{array}$} & 5 & EATL $\otimes$ & $\begin{array}{l}\text { Chop, surgery and } \\
\text { ASCT }\end{array}$ & & $\begin{array}{l}1 \text { year } 100 \% \otimes 5 \\
\text { years } 33 \%\end{array}$ \\
\hline & 19 & EATL $\otimes$ & Chop, surgery & & $\begin{array}{l}1 \text { year } 73 \% \otimes 5 \text { years } \\
14 \%\end{array}$ \\
\hline & 12 & EATL $\otimes$ & Chop & & $\begin{array}{l}1 \text { year } 17 \% \bigotimes 5 \text { years } \\
0 \%\end{array}$ \\
\hline & 12 & EATL $\otimes$ & Surgery & & $\begin{array}{l}1 \text { year } 17 \% \otimes 5 \text { years } \\
8 \%\end{array}$ \\
\hline
\end{tabular}


Table 2

Timeline of diagnosis and treatment process

Time Events

July 21, 2019 The patient went to the local hospital with defecating black stool.

July 24, 2019 The patient was transferred to Xianyang Central Hospital.

August 1, 2019 The patient refused further examination, was discharged from the Xianyang Central Hospital.

September 4, The patient returned to Xianyang Central Hospital with defecating black stool. 2019

September 20, The pathological results came out, monomorphic epitheliotropic T-cell lymphoma 2019 was considered.

September 22, The patient was transferred to Xijing Hospital of Air Force military Medical 2019 University for further treatment.

March 10, No recurrence or metastasis has been found in an 18-months follow-up after 2021 treatment.

\section{Abbreviations}

EATL: Enteropathy-associated T cell lymphoma; MEITL: monomorphic epitheliotropic intestinal T-cell lymphoma; ASCT: autologous stem cell transplantation

\section{Declarations}

\section{Acknowledgements}

The authors thank Qin-Xun Guo, MD, for kindly revised the first draft.

\section{Date availability statement}

The original contributions presented in the study are included in the article/supplementary material. Further inquiries can be directed to the corresponding author.

\section{Ethics statement}

Written informed consent was obtained from the patient for the publication of any potentially identifiable images or data included in this article.

\section{Authors contributions}

Corresponding author: Lin Yang. Preparation of graphical material: Xiao-Yan Ma, Rui-Ni Li. postprocessing and completed the manuscript: Cheng Zhou, Hai-Juan Xiao, Yu Fang. All authors contributed 
to the article and approved the submitted version.

\section{Funding}

This work was supported by the Subject Innovation Team of Shaanxi University of Chinese Medicine(No.2019-YL06), the National Natural Science Foundation of China(No. 82074255), Natural Science Foundation of Shaanxi Province (No.2020JM-591).

\section{Conflict of Interest}

The authors declare that the research was conducted in the absence of any commercial or financial relationships that could be construed as a potential conflict of interest.

\section{Consent for publication}

Informed consent was obtained from the patient.

\section{References}

1. Delabie J, Holte H, Vose JM, Ullrich F, Jaffe ES, Savage KJ, et al. Enteropathy-associated T-cell lymphoma: clinical and histological findings from the international peripheral T-cell lymphoma project. Blood (2011) 118(1):148-55. doi: 10.1182/blood-2011-02-335216.

2. Verbeek WH, Van De Water JM, Al-Toma A, Oudejans JJ, Mulder CJ, Coupé VM. Incidence of enteropathy--associated T-cell lymphoma: a nation-wide study of a population-based registry in The Netherlands. Scand J Gastroenterol (2008) 43(11):1322-8. doi: 10.1080/00365520802240222.

3. Jaffe ES. The 2008 WHO classification of lymphomas: implications for clinical practice and translational research. Hematology Am Soc Hematol Educ Program (2009)523-31. doi: 10.1182/asheducation-2009.1.523.

4. Swerdlow SH, Campo E, Pileri SA, Harris NL, Stein H, Siebert R, et al. The 2016 revision of the World Health Organization classification of lymphoid neoplasms. Blood (2016) 127(20):2375-90. doi: 10.1182/blood-2016-01-643569.

5. Ogata M, Ota Y, Nanno M, Suzuki R, Itoh T. Activation of intra-epithelial lymphocytes; their morphology, marker expression and ultimate fate. Cell Tissue Res (2014) 356(1):217-30. doi: 10.1007/s00441-013-1786-4.

6. Moffitt AB, Ondrejka SL, McKinney M, Rempel RE, Goodlad JR, Teh CH, et al. Enteropathy-associated T cell lymphoma subtypes are characterized by loss of function of SETD2. J Exp Med (2017) 214(5):1371-1386. doi: 10.1084/jem.20160894.

7. Tomita S, Kikuti YY, Carreras J, Kojima M, Ando K, Takasaki H, et al. Genomic and immunohistochemical profiles of enteropathy-associated T-cell lymphoma in Japan. Mod Pathol (2015) 28(10):1286-96. doi: 10.1038/modpathol.2015.85. 
8. van Vliet C, Spagnolo DV. T- and NK-cell lymphoproliferative disorders of the gastrointestinal tract: review and update. Pathology (2020) 52(1):128-141. doi: 10.1016/j.pathol.2019.10.001.

9. Susan SH, Ng SB, Wang S, Tan SY. Diagnostic approach to T- and NK-cell lymphoproliferative disorders in the gastrointestinal tract. Semin Diagn Pathol (2021) 38(4):21-30. doi: 10.1053/j.semdp.2021.03.004.

10. Song SS, Yu L, Zhou XM, Duan CF, Sui QL, Wang G. Diagnostic value and charactertics of CT enterography in primary intestinal T-cell lymphoma. Chinese Journal of Medical Imaging Technology (2017) 33(07):1010-1013.

11. Montes-Moreno S, King RL, Oschlies I, Ponzoni M, Goodlad JR, Dotlic S, et al. Update on lymphoproliferative disorders of the gastrointestinal tract: disease spectrum from indolent lymphoproliferations to aggressive lymphomas. Virchows Arch (2020) 476(5):667-681. doi: 10.1007/s00428-019-02704-8.

12. Wenzinger C, Williams E, Gru AA. Updates in the Pathology of Precursor Lymphoid Neoplasms in the Revised Fourth Edition of the WHO Classification of Tumors of Hematopoietic and Lymphoid Tissues. Curr Hematol Malig Rep (2018) 13(4):275-288. doi: 10.1007/s11899-018-0456-8.

13. Perry AM, Warnke RA, Hu Q, Gaulard P, Copie-Bergman C, Alkan S, et al. Indolent T-cell lymphoproliferative disease of the gastrointestinal tract. Blood (2013) 122(22):3599-606. doi: 10.1182/blood-2013-07-512830.

14. Gale J, Simmonds PD, Mead GM, Sweetenham JW, Wright DH. Enteropathy-type intestinal T-cell lymphoma: clinical features and treatment of 31 patients in a single center. J Clin Oncol (2000) 18(4):795-803. doi: 10.1200/JC0.2000.18.4.795.

15. Nijeboer P, de Baaij LR, Visser $\mathrm{O}$, Witte BI, Cillessen SA, Mulder CJ, et al. Treatment response in enteropathy associated T-cell lymphoma; survival in a large multicenter cohort. Am J Hematol (2015) 90(6):493-8. doi: 10.1002/ajh.23992.

16. Sieniawski M, Angamuthu N, Boyd K, Chasty R, Davies J, Forsyth P, et al. Evaluation of enteropathyassociated T-cell lymphoma comparing standard therapies with a novel regimen including autologous stem cell transplantation. Blood (2010) 115(18):3664-70. doi: 10.1182/blood-2009-07231324.

17. Han X, Zhang W, Zhou D, Ruan J, Duan M, Zhu T, et al. Autologous stem cell transplantation as frontline strategy for peripheral T-cell lymphoma: A single-centre experience. J Int Med Res (2017) 45(1):290-302. doi: 10.1177/0300060516676725.

18. Phillips EH, Lannon MM, Lopes A, Chadwick H, Jones G, Sieniawski M, et al. High-dose chemotherapy and autologous stem cell transplantation in enteropathy-associated and other aggressive T-cell lymphomas: a UK NCRI/Cancer Research UK Phase II Study. Bone Marrow Transplant (2019) 54(3):465-468. doi: 10.1038/s41409-018-0294-2.

19. Bishton MJ, Haynes AP. Combination chemotherapy followed by autologous stem cell transplant for enteropathy-associated T cell lymphoma. Br J Haematol (2007) 136(1):111-3. doi: 10.1111/j.13652141.2006.06371. 
20. Jantunen E, Boumendil A, Finel H, Luan JJ, Johnson P, Rambaldi A, et al. Autologous stem cell transplantation for enteropathy-associated T-cell lymphoma: a retrospective study by the EBMT. Blood (2013) 121(13):2529-32. doi: 10.1182/blood-2012-11-466839.

21. d'Amore F, Relander T, Lauritzsen GF, Jantunen E, Hagberg H, Anderson $H$, et al. Up-front autologous stem-cell transplantation in peripheral T-cell lymphoma: NLG-T-01. J Clin Oncol (2012) 30(25):3093-9. doi: 10.1200/JCO.2011.40.2719.

22. Tse E, Gill H, Loong F, Kim SJ, Ng SB, Tang T, et al. Type II enteropathy-associated T-cell lymphoma: a multicenter analysis from the Asia Lymphoma Study Group. Am J Hematol (2012) 87(7):663-8. doi: 10.1002/ajh.23213.

23. Nairismägi ML, Tan J, Lim JQ, Nagarajan S, Ng CC, Rajasegaran V, et al. JAK-STAT and G-proteincoupled receptor signaling pathways are frequently altered in epitheliotropic intestinal T-cell lymphoma. Leukemia (2016) 30(6):1311-9. doi: 10.1038/leu.2016.13.

24. Voorhees TJ, Ghosh N, Grover N, Block J, Cheng C, Morrison K, et al. Long-term remission in multiply relapsed enteropathy-associated T-cell lymphoma following CD30 CAR T-cell therapy. Blood Adv (2020)4(23):5925-5928. doi: 10.1182/bloodadvances. 2020003218.

\section{Figures}




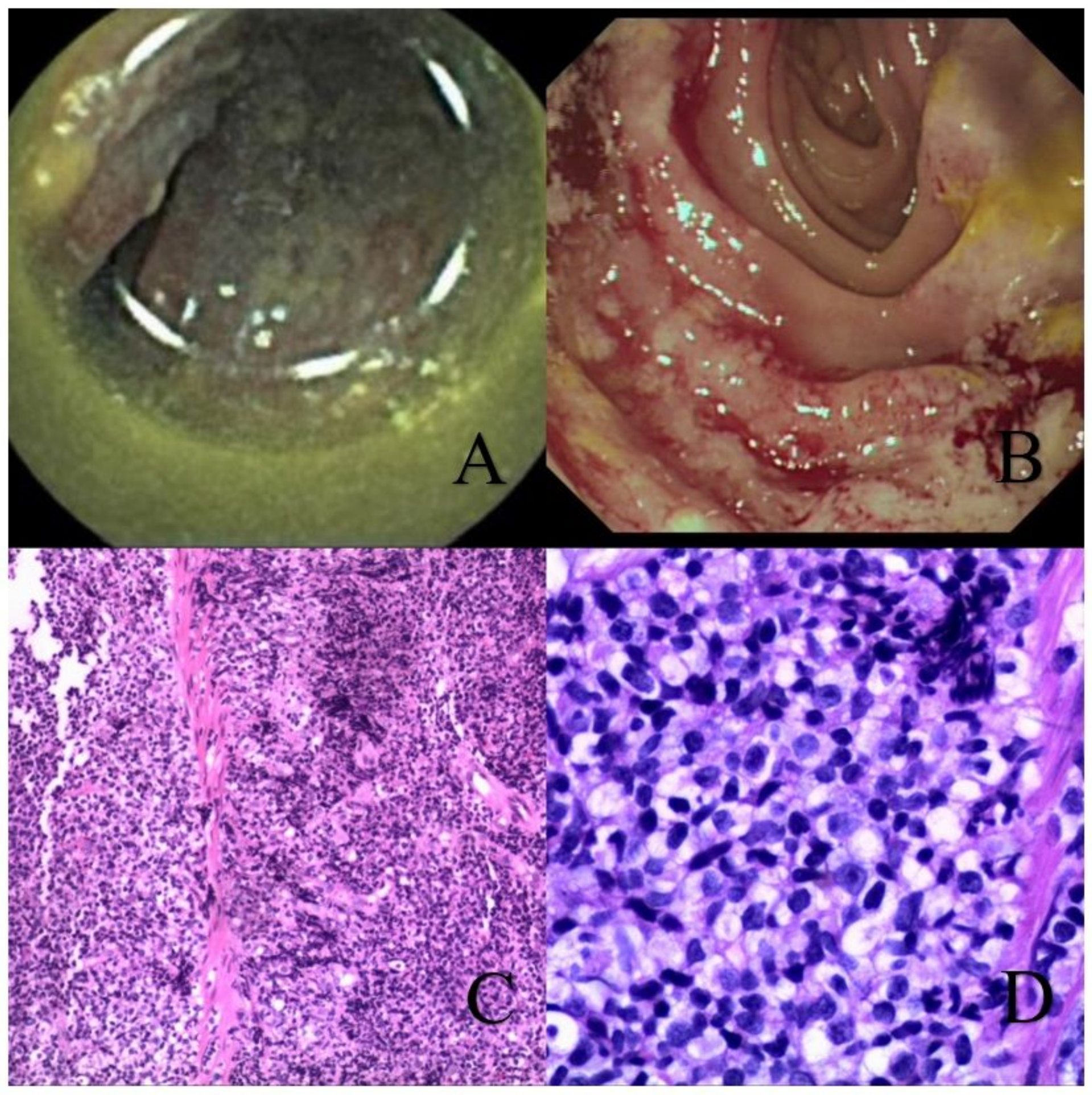

\section{Figure 1}

1A: Capsule endoscopy The intestinal preparation was poor, multiple deep basement depressions could be seen in the jejunal mucosa. 1B: Single balloon enteroscopy Large patches of ulcerative lesions were seen in the upper jejunum 1C 1D: Histologic appearance of monomorphic epitheliotropic intestinal T-cell lymphoma The cells were equal, lightly stained cytoplasm, obvious nucleolus, and mitosis. 1C: HEx100 1D: HEx400 


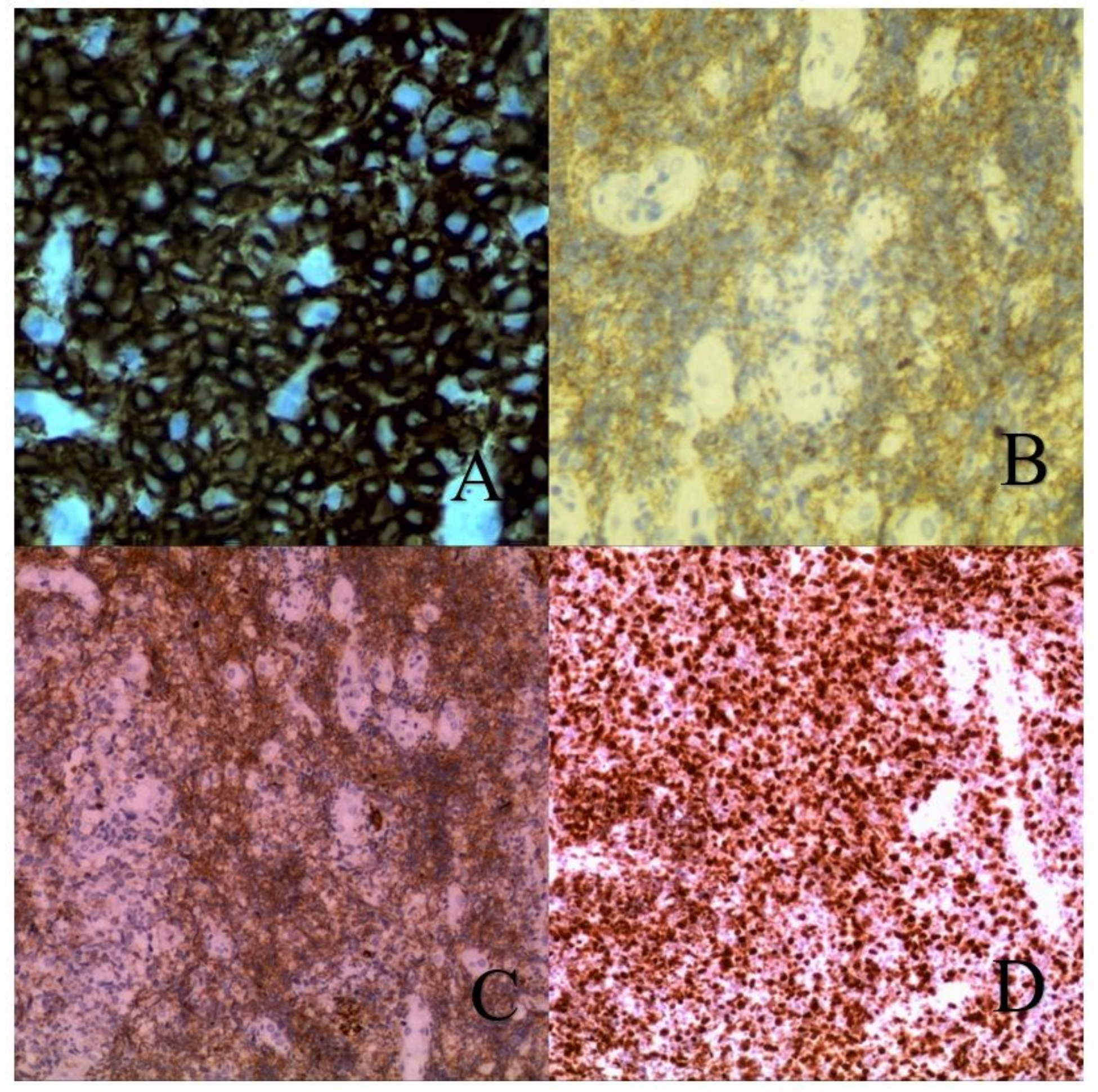

Figure 2

2A: CD3 immunohistochemical staining 2B: CD8 immunohistochemical staining 2C: CD56 immunohistochemical staining 2D: The proliferation index of Ki-67 was $80 \%$ immunohistochemical staining

\section{Supplementary Files}


This is a list of supplementary files associated with this preprint. Click to download.

- carechecklist.jpg 